\title{
PENERAPAN PUPUK ORGANIK CAIR (Bahan Aktif Aspergillus sp.) BERBAHAN DASAR LIMBAH CAIR TEMPE DAN AIR KELAPA PADA TANAMAN KANGKUNG DARAT (Ipomoea reptans Poir.)
}

\section{Application of Liquid Organic Fertilizer (Active Ingredient Aspergillus sp.) Liquid Waste Based on Tempe and Coconut Water on Kangkung Land Plant (Ipomoea reptans poir.)}

\author{
Miranty Sirappa ${ }^{1)}$, Umrah $^{1)}$, Abdul Rahim Thaha ${ }^{2)}$ \\ 1)Jurusan Biologi Fakultas MIPA, Universitas Tadulako, Palu JI. Soekarno-Hatta Km 9, Tondo \\ Palu, Sulawesi Tengah 94117 \\ 2)Jurusan Agroteknologi Fakultas Pertanian, Universitas Tadulako, Palu Jl. Soekarno-Hatta \\ Km 9, Tondo Palu, Sulawesi Tengah 94117
}

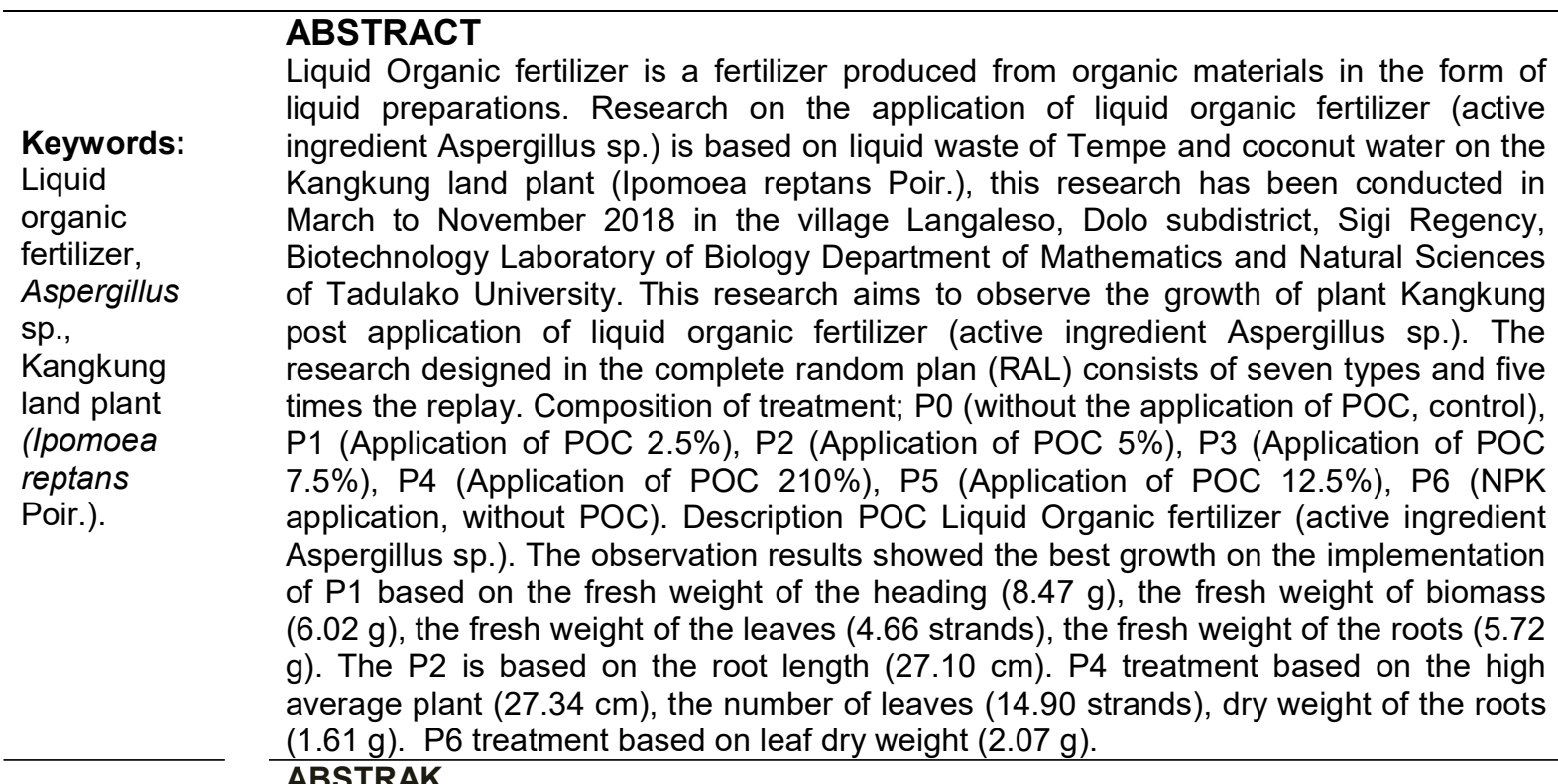

\section{ABSTRAK}

Pupuk organik cair adalah pupuk yang diproduksi dari bahan-bahan organik dalam bentuk sediaan cair. Penelitian tentang penerapan pupuk organik cair (Bahan Aktif Aspergillus sp.) berbahan dasar limbah cair tempe dan air kelapa pada tanaman Kata Kunci: $\quad$ kangkung darat (Ipomoea reptans Poir.), Penelitian ini telah dilaksanakan pada bulan Produktivitas Maret sampai November 2018 di Desa Langaleso, Kecamatan Dolo, Kabupaten Sigi, primer, Fitoplankton, Danau Sibili, Kota Palu Laboratorium Bioteknologi Jurusan Biologi Fakultas Matematika dan Ilmu Pengetahuan Alam Universitas Tadulako. Penelitian ini bertujuan untuk mengamati pertumbuhan tanaman kangkung pasca penerapan pupuk organik cair (Bahan Aktif Aspergillus sp.). Penelitian didesain dalam Rancangan Acak Lengkap (RAL) terdiri dari tujuh perlakan dan lima kali ulangan. Susunan perlakuan; P0 (tanpa penerapan POC, kontrol), P1 (penerapan POC 2,5\%), P2 (penerapan POC 5\%), P3 (penerapan POC 7,5\%), P4 (penerapan POC 210\%), P5 (penerapan POC 12,5\%), P6 (penerapan NPK, tanpa POC). Keterangan POC pupuk organik cair (Bahan Aktif Aspergillus sp.). Hasil pengamatan menunjukkan pertumbuhan terbaik pada pelakuan $\mathrm{P} 1$ berdasarkan berat segar tajuk $(8,47 \mathrm{~g})$, berat segar biomassa $(6,02 \mathrm{~g})$, berat segar daun $(4,66$ helai), berat segar akar (5,72 g). Pelakuan P2 berdasarkan panjang akar $(27,10 \mathrm{~cm})$. perlakuan P4 berdasarkan rata-rata tinggi tanaman $(27,34 \mathrm{~cm})$, jumlah daun (14,90 helai), berat kering akar $(1,61 \mathrm{~g})$. Perlakuan P6 berdasarkan berat kering daun $(2,07 \mathrm{~g})$.

\footnotetext{
Corresponding Author : mirantysirappa@gmail.com
} 


\section{PENDAHULUAN}

Tanaman kangkung darat merupakan salah satu jenis tanaman yang memiliki nilai ekonomis yang tinggi dalam keanekaragaman pangan yang bergizi. Tanaman kangkung juga merupakan sumber gizi dan memiliki harga yang terjangkau dan mudah didapatkan. Tanaman kangkung juga memiliki sumber vitamin $A$ dan mineral serta unsur gizi yang berfungsi bagi kesehatan tubuh dan dapat menenangkan syaraf. Di Indonesia tanaman kangkung terbagi atas dua yaitu: tanaman kangkung darat dan tanaman kangkung berair (Ariyono dkk., 2014).

Kangkung darat (I. reptans Poir.) merupakan salah satu tanaman hortikultura yang sangat digemari oleh masyarakat Indonesia karena rasanya yang gurih. Tanaman ini termasuk kelompok tanaman semusim dan berumur pendek karena biasanya pasca tanam 3045 hari akan dipanen dan tidak memerlukan areal yang luas untuk membudidayakannya sehingga memungkinkan dibudidayakan di kota yang pada umumnya lahannya terbatas. Selain rasanya yang gurih, kandungan gizi yang terdapat pada sayuran kangkung cukup tinggi, seperti vitamin A, B dan C serta berbagai mineral terutama zat besi yang berguna bagi pertumbuhan badan dan kesehatan Kangkung mempunyai senyawa yang dapat digunakan untuk pengobatan bagi penderita susah tidur. Tanaman kangkung juga bermanfaat sebagai obat penenang saraf, obat sakit ISSN-P : 1978-6417; ISSN-E : 2580-5991 kepala. Serat pada kangkung juga sangat baik untuk mencegah konstipasi sehingga dapat menghalangi terjadinya kanker perut. Karetenoid dalam tubuh akan diubah menjadi vitamin A serta klorofil tinggi (Hapsari dkk., 2014).

Pupuk organik cair banyak digunakan karena memiliki kelebihan dibanding pupuk organik padat. Pupuk organik dapat berbentuk padat atau cair yang digunakan untuk memperbaiki sifat fisik, kimia, dan biologi tanah. Pupuk organik cair tidak merusak tanah dan tanaman yang mempunyai larutan pengikat. Jika diaplikasikan dapat digunakan oleh tanaman dan diberikan melalui akar maupun daun tanaman dan mudah diserap karena unsur haranya sudah terurai (Duaja, 2012).

Pupuk organik cair merupakan salah satu jenis pupuk yang banyak beredar di pasaran. Pupuk organik cair kebanyakan diaplikasikan melalui daun atau disebut sebagai pupuk cair foliar yang mengandung hara makro dan mikro esensial (N, P, K, S, Ca, Mg, B, Mo, Cu, $\mathrm{Fe}, \mathrm{Mn}$, dan bahan organik). Pupuk organik cair mempunyai beberapa manfaat diantaranya dapat mendorong dan meningkatkan pembentukan klorofil daun dan pembentukan bintil akar pada tanaman leguminosae sehingga meningkatkan kemampuan fotosintesis tanaman dan penyerapan nitrogen dari udara, dapat meningkatkan vigor tanaman sehingga tanaman menjadi kokoh dan kuat, meningkatkan daya tahan tanaman 
terhadap kekeringan, cekaman cuaca dan serangan patogen penyebab penyakit (Rizqiani dkk., 2007).

Limbah Tempe merupakan salah satu makanan yang banyak gemari oleh masyarakat. Selain murah, tempe juga banyak mengandung protein karena bahan dasarnya yang berupa biji kedelai (Rachmayanti, 2015).

Air kelapa merupakan salah satu produk dari tanaman kelapa yang belum banyak dimanfaatkan. Air kelapa muda merupakan minuman yang sangat popular dan air kelapa dari buah yang tua juga telah dikembangkan sebagai produk industri namun pemasarannya masih terbatas. Air kelapa mengandung berbagai asam amino, dan air kelapa juga mengandung hormon sitokinin $(5,8 \mathrm{mg} / \mathrm{l})$, auksin $(0,07 \mathrm{mg} / \mathrm{l})$, sedikit giberelin serta senyawa lain yang dapat menstimulus perkecambahan dan pertumbuhan. Pemberian $250 \mathrm{ml} / \mathrm{l}$ air kelapa dapat menunjukkan waktu yang paling cepat dalam perkecambahan biji anggrek macan (Karimah dkk., 2013).

Air kelapa mengandung nutrisi alami seperti garam-garam mineral, beberapa macam gula, vitamin, protein, zat pengatur tumbuh dan lemak netral. Air kelapa bermanfaat meningkatkan petumbuhan tanaman karena air kelapa kaya akan kandungan gula antara 1,7 sampai 2,6\% dan protein 0,07 hingga $0,55 \%$. Mineral lainnya antara lain natrium $(\mathrm{Na})$, kalsium (Ca), magnesium (Mg), ferum (Fe), cuprum (Cu), fosfor $(P)$ dan sulfur (S). ISSN-P : 1978-6417; ISSN-E : 2580-5991
Disamping kaya mineral, air kelapa juga mengandung berbagai macam vitamin seperti asam sitrat, asam nikotinat, asam pantotenal, asam folat, niacin, riboflavin, dan thiamin (Rahayu \& Martono, 2015).

\section{BAHAN DAN METODE}

Bahan yang digunakan pada penelitian ini adalah limbah cair tempe yang diambil dari desa Langaleso, air kelapa, plastik tahan panas, alkohol, kultur jamur Aspergillus sp. yang diperoleh dari Laboratorium Bioteknologi Jurusan Biologi FMIPA Universitas Tadulako. Alat-alat yang digunakan pada penelitian ini adalah galon, pollybag $25 \times 30 \mathrm{~cm}$, alat tulis menulis, gelas ukur $100 \mathrm{ml}$, plastik tahan panas, wadah, kamera, aerator, selang aerator, timbangan, neraca analitik, gunting, autoclave, oven.

\section{Rancangan Penelitian}

Penelitian didesain dalam Rancangan Acak Lengkap (RAL) yang terdiri dari tujuh perlakuan dan lima kali ulangan, sehingga diperoleh tiga puluh lima unit percobaan. Susunan perlakuan sebagai berikut : Penelitian didesain dalam Rancangan Acak Lengkap (RAL) terdiri dari tujuh perlakan dan lima kali ulangan. Susunan perlakuan; PO (tanpa penerapan POC, kontrol), P1 (penerapan POC 2,5\%), P2 (penerapan POC 5\%), P3 (penerapan POC 7,5\%), P4 (penerapan POC 210\%), P5 (penerapan POC 12,5\%), P6 (penerapan NPK, tanpa POC). 
Keterangan :

PC-LCT : Pupuk cair- Limbah Cair
Tempe

\section{Penyediaan Jamur Aspergillus sp.}

Pupuk organik cair menggunakan jamur Aspergillus sp. dalam bentuk sediaan pellet-granul sebanyak $50 \mathrm{~g}$ yang diperoleh dari Laboratorium Bioteknologi FMIPA Jurusan Biologi Universitas Tadulako.

\section{Pembuatan Media Formula}

Media yang digunakan yaitu limbah cair tempe dan air kelapa, komposisi yang digunakan yaitu limbah cair tempe 25\% dan air kelapa 25\%. Masing-masing di sterilkan dengan autoclave dengan suhu $121^{\circ} \mathrm{C}$ selama 15 menit. Dan media siap digunakan untuk pembiakan Aspergillus sp.

\section{Inokulum jamur Aspergillus sp.}

Jamur Aspergillus sp. dimasukkan kedalam media formula sebanyak 500 gram kemudian ditutup dan diaerasi selama 3 hari menggunakan aerator.

\section{Tahap Penyiapan media tanam}

Media yang akan digunakan untuk menanam kangkung adalah tanah dengan campuran sekam padi dan abu yang dimasukkan kedalam pollybag. Sebelum dimasukkan media, dasar pollybag diberikan lubang kecil dengan diameter kurang lebih $1 \mathrm{~cm}$, kemudian media dimasukkan kedalam pollybag yang berukuran $25 \times 30 \mathrm{~cm}$.

\section{Penanaman}

Penanaman benih kangkung dilakukan di Desa Langaleso, Kecamatan Dolo, Kabupaten Sigi. Benih kangkung darat yang akan ditanam direndam terlebih dahulu selama 1-2 jam guna mempercepat pemecahan dormansi benih. Benih yang ditanam sebanyak 3 benih dalam satu pollybag, penanaman tepat dilakukan di tengah media tanam dan dilakukan pada sore hari (Ariyono dkk., 2014).

\section{Aplikasi Pupuk Organik Cair}

Pupuk organik cair bahan dasar limbah cair tempe dan air kelapa diberikan sebanyak 2 kali yaitu pada minggu pertama dan minggu kedua setelah tanam. Komposisi pupuk cair bahan dasar limbah cair tahu yang diberikan secara berturut-turut yaitu P0 (Tanpa aplikasi PCLCT (kontrol)), P1 (PC-LCT 2,5\% + Air 497,5\%) dalam volume $500 \mathrm{ml}$, P2 (PCLCT 5\% + Air 495\%) dalam volume 500 ml, P3 (PC-LCT 7,5\% + Air 492,5\%) dalam Volume 500 ml, P4 (PC-LCT 10\% + Air $490 \%$ ) dalam volume $500 \mathrm{ml}$, P5 (PCLCT 10,5 + Air 489,5\%) dalam volume $500 \mathrm{ml}$, P6 (NPK 1,5 gr + Air 500\%). Pemanenan kangkung dilakukan saat umur tanaman kangkung +20 hari setelah tanam. Cara panen ialah dengan cara mencabut tanaman sampai akarnya atau memotong pada bagian pangkal tanaman sekitar $2 \mathrm{~cm}$ di atas permukaan tanah. 
Pemeliharaan

Pemeliharaan tumbuhan dilakukan selama masa tanam hingga masa pemanenan melalui perawatan pada tumbuhan.

\section{Pemanenan}

Pemanenan tanaman kangkung dilakukan saat tanaman berumur 20 hari setelah tanam.

\section{Pengamatan Penelitian}

1. Tinggi tanaman $(\mathrm{cm})$

Pengukuran dimulai saat tanaman berumur 5 hari setelah tanam sampai berumur 20 hari. Interval pengukurannya yaitu 5 hari sekali, diukur dengan menggunakan mistar dan diukur dari pangkal batang hingga bagian pucuk.

2. Jumlah daun (helai)

Penghitungan terhadap jumlah daun dilakukan setiap 5 hari sekali. Daun yang dihitung adalah daun yang telah membuka sempurna.

3. Berat biomassa (gr)

Pengamatan berat biomassa tanaman dilakukan setelah selesai panen dengan cara menimbang tanaman tanpa akar.

4. Berat segar dan kering akar (gr)

\section{HASIL}

\section{Tinggi Tanaman (cm)}

Hasil dari analisis statistik menunjukan bahwa pemberian pupuk organik cair yang berpengaruh nyata terhadap tinggi tanaman kangkung. Rata-rata tinggi
Berat segar dan kering akar dilakukan pada saat sesudah panen. Kemudian akar dikeringkan menggunakan oven dengan temperatur $70 \circ \mathrm{C}$ selama 24 jam, dan setelah itu ditimbang.

5. Berat segar tajuk (gr)

Pengamatan berat segar tajuk dilakukan setelah selesai panen dan menimbang tanpa akar.

6. Berat segar dan kering daun (gr) Berat segar dan kering daun dilakukan setelah tanaman dipanen dan daun dikeringkan menggunakan oven dengan bertemperatur $70 \circ \mathrm{C}$ selama 24 jam, dan setelah itu ditimbang menggunakan neraca analitik.

7. Panjang akar $(\mathrm{cm})$

Panjang akar diukur pada waktu selesai panen.

\section{ANALISIS DATA}

Data yang didapatkan dari hasil pengamatan dilakukan analisis ragam "ANOVA" one way anova dengan menggunakan software statistika versi 7 , dan jika terjadi perbedaan terhadap masing-masing perlakuan maka akan dilakukan uji lanjut Duncan pada taraf 5\%.

tanaman pada setiap perlakuan dapat dilihat pada gambar 1 


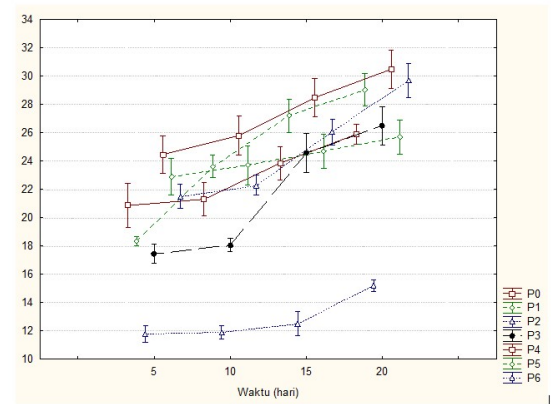

Gambar 1 Rata-rata tinggi tanaman tiap minggu.

Nilai rata-rata pada tanaman kangkung darat (Ipomoea reptans Poir.) tertinggi adalah P4 $(27,34 \mathrm{~cm})$ kemudian disusul oleh P6 $(24,88 \mathrm{~cm})$, P1 $(24,54 \mathrm{~cm})$, P5 $(24,22 \mathrm{~cm})$, P0 $(22,78 \mathrm{~cm})$, P3 $(21,63 \mathrm{~cm})$ dan yang terendah adalah P2 $(12,83 \mathrm{~cm})$. Hal ini menunjukkan bahwa pemberian "pupuk organik cair " berpengaruh nyata terhadap pertumbuhan tanaman kangkung darat. Nilai rata-rata pada tanaman yang tertinggi yaitu $\mathrm{P} 4$, dan nilai yang terendah yaitu P6. Peningkatan tinggi tanaman terjadi karena unsur nitrogen yang mampu mempengaruhi pertumbuhan meristem apikal untuk dapat berkembang. Dan pupuk organik cair berperan untuk meningkatkan sifat fisik, kimia dan biologi tanah karena mengandung unsur hara yang dapat meningkatkan pertumbuhan tanaman. (Rahmah dkk, 2014).

\section{Jumlah Daun (helai)}

Hasil dari analisis statistik menunjukkan bahwa pemberian pupuk organik cair berpengaruh nyata terhadap jumlah daun. Rata-rata jumlah daun pada tiap perlakuan dapat dilihat pada gambar 2 .

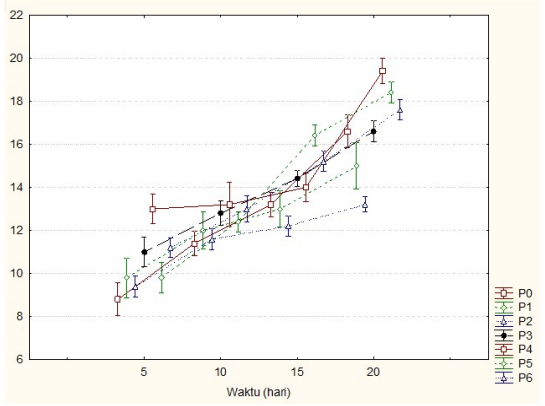

Gambar 2 Rata-rata jumlah daun

Gambar 2 menunjukkan bahwa nilai ratarata jumlah daun pada tanaman kangkung darat (Ipomoea reptans Poir.) tertinggi adalah adalah P4 (14,90 helai) kemudian disusul oleh P5 (14,25 helai), P6 (14,25 helai), P3 (13,7 helai), P0 (12,50 helai), P1 (12,45 helai) dan yang terendah adalah P2 (11,60 helai).

Berdasarkan hasil penelitian yang dilakukan menunjukkan bahwa pemberian "pupuk organik cair" berpengaruh nyata terhadap jumlah daun. Dimana pada P4 memiliki jumlah daun terbanyak, dan P2 memiliki jumlah daun paling sedikit. Hal ini dikarenakan adanya nitrogen yang dapat mempercepat proses fotosintesis sehingga pembentukan organ daun menjadi lebih cepat, dan pertumbuhan, perkembangan tanaman akan menjadi baik (Rahmah dkk, 2014).

\section{Biomassa}

Hasil dari analisis statistik menunjukkan bahwa pemberian pupuk organik cair berpengaruh nyata terhadap berat biomassa. Rata-rata berat biomassa pada tiap perlakuan dapat dilihat pada gambar 


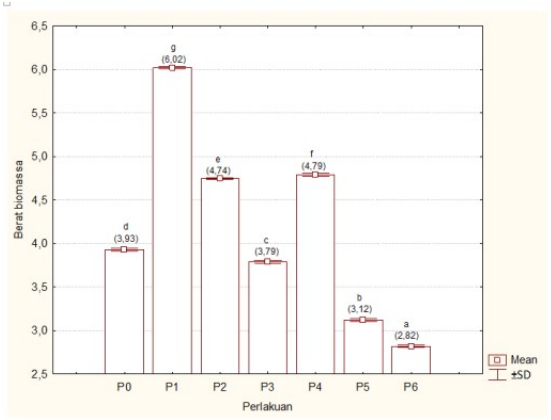

Gambar 3 Rata-rata berat biomassa

Gambar 3 menunjukkan bahwa nilai ratarata berat biomassa pada tanaman kangkung darat (Ipomoea reptans Poir.) tertinggi adalah adalah P1 (6,02 g), kemudian disusl oleh P4 (4,79 g), P2 (4,74 g), P0 (3,93 g), P3 (3,79 g), P5 (3,12 g) dan yang terendah adalah P6 (2,82 g).

Berdasarkan hasil penelitian yang dilakukan menunjukkan bahwa pemberian pupuk organik cair berpengaruh nyata terhadap berat biomassa. Nilai rata-rata pada tanaman yaitu $\mathrm{P} 1$, dan nilai rata-rata yang terendah yaitu P6. Peningkatan biomassa dikarenakan pada konsentrasi tersebut tanaman menyerap air dan hara lebih banyak,unsur hara memacu perkembangan organ pada tanaman sehingga tanaman dapat menyerap hara dan air lebih banyak dan ketersediaan unsur hara berperan penting sebagai sumber energi sehingga tingkat kecukupan hara berperan dalam mempengaruhi biomassa dari suatu tanaman (Rahmah dkk, 2014).

\section{Berat Segar Tajuk (g)}

Hasil dari analisis statistik menunjukkan bahwa pemberian pupuk organik cair berpengaruh nyata terhadap berat tajuk segar. Rata-rata berat segar tajuk pada tiap perlakuan dapat dilihat pada gambar 4.4

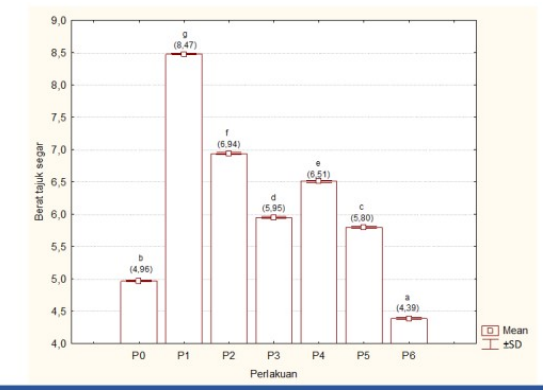

Gambar 4 Rata-rata berat segar tajuk

Gambar 4 menunjukkan bahwa nilai ratarata berat tajuk segar pada tanaman kangkung darat (Ipomoea reptans Poir.) tertinggi adalah P1 (8,47 g), kemudian disusul oleh P2 (6,94 g), P4 (6,51 g), P3 (5,95 g), P5 (5,80 g), P0 (4,96 g) dan yang terendah adalah P6 $(4,39 \mathrm{~g})$.

Hasil Pengamatan menunjukkan bahwa pemberian pupuk organik cair berpengaruh nyata terhadap berat segar tajuk. Nilai rata-rata tertinggi yaitu $\mathrm{P} 1$, dan nilai rata-rata terendah yaitu $\mathrm{P} 6$. Hal ini disebabkan karena turgor yang ada pada batang dan daun akibat dari kandungan nitrogen yang banyak terdapat didalam tubuh tanaman akibat penyerapan unsur hara. Air yang ada di batang dan daun tidak dapat menguap dan akan menyebabkan bagian-bagian tersebut tetap basah. Darwin (2012) menyatakan bahwa jumlah daun akan berpengaruh terhadap bobot berat segar tajuk, semakin banyak jumlah daun maka semakin tinggi berat segar tajuk. Berat segar tajuk 
merupakan gambaran dari fotosintesis selama tanaman melakukan proses pertumbuhan. Dan ketersediaan unsur hara yang terdapat pada pupuk organik cair dapat diserap melalui akar sehingga mempengaruhi hasil fotosintesis yang mempengaruhi berat segar tajuk.

\section{Berat Segar dan Kering Daun (g)}

Hasil dari analisis statistik menunjukkan bahwa pemberian pupuk organik cair berpengaruh nyata terhadap berat segar dan kering daun. Rata-rata berat segar dan kering daun pada tiap perlakuan dapat dilihat pada gambar 5

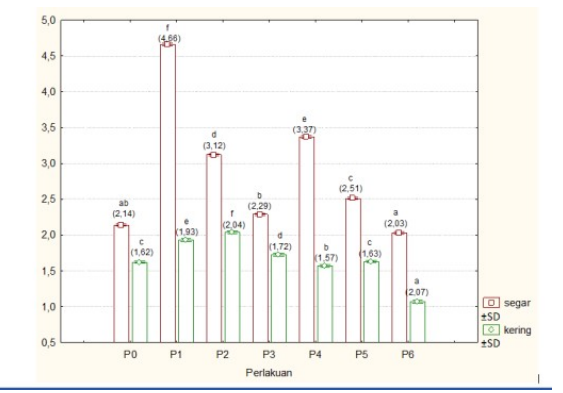

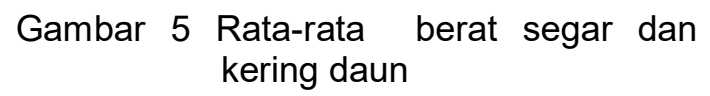

Gambar 5 menunjukkan bahwa nilai ratarata berat segar daun pada tanaman kangkung darat (Ipomoea reptans Poir.) tertinggi adalah P1 (4,66 g) kemudian disusul oleh P4 (3,37 g), P2 (3,12 g), P5 (2,51 g), P3 (2,29 g), P0 (2,14 g) dan yang terendah adalah P6 (2,03 g). Sedangkan nilai rata-rata berat kering daun tertinggi adalah P6 (2,07 g) disusul oleh P2 (2,04 g), P1 (1,93 g), P3 (1,72 g), P5 (1,63 g), P0 (1,62 g) dan yang terendah adalah P4 $(1,57 \mathrm{~g})$.
Hasil pengamatan menunjukkan bahwa pemberian pupuk organik cair berpengaruh nyata terhadap berat segar dan kering daun. Nilai rata-rata berat segar daun adalah P1 dan yang terendah adalah P6. Dan nilai rata-rata berat kering daun adalah P6, dan nilai terendah yaitu P4. Hal ini dikarenakan daun banyak mengandung nitrogen sehingga mempermudah pertumbuhan pada tanaman.

\section{Berat Segar dan Kering Akar (g)}

Hasil dari analisis statistik menunjukkan bahwa pemberian pupuk organik cair berpengaruh nyata terhadap berat segar dan kering akar. Rata-rata berat segar dan kering akar pada tiap perlakuan dapat dilihat pada gambar 6

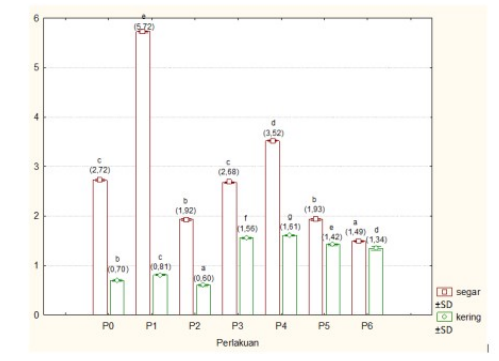

Gambar $6 \begin{gathered}\text { Rata-rata berat segar dan } \\ \text { kering akar }\end{gathered}$ Gambar 6 menunjukkan bahwa nilai ratarata berat segar akar pada tanaman kangkung darat (Ipomoea reptans Poir.) tertinggi adalah P1 (5,72 g), kemudian disusul oleh P4 (3,54 g), P0 (2,72 g), P3 (2,68 g), P5 (1,93 g), P2 (1,92 g) dan yang terendah adalah P6 (1,49 g). Sedangkan nilai rata-rata berat kering akar adalah $\mathrm{P} 4$ $(1,61 \mathrm{~g})$, kemudian disusul oleh P3 (1,56 g), P5 (1,42 g), P6 (1,34 g), P1 (0,81 g), 
P0 $(0,70 \mathrm{~g})$ dan yang terendah adalah P2 $(0,60 \mathrm{~g})$.

Hasil pengamatan menunjukkan bahwa pemberian pupuk organik cair berpengaruh nyata terhadap berat segar akar dan kering akar. Nilai rata-rata berat segar akar tertinggi yaitu $\mathrm{P} 1$, dan yang terendah yaitu P4. Dan nilai kering akar tertinggi yaitu $\mathrm{P} 4$, dan nilai terendah yaitu P2.

\section{Panjang Akar (cm)}

Hasil dari analisis statistik menunjukkan bahwa pemberian pupuk organik cair berpengaruh nyata terhadap berat segar tajuk. Rata-rata panjang akar pada tiap perlakuan dapat dilihat pada gambar 7

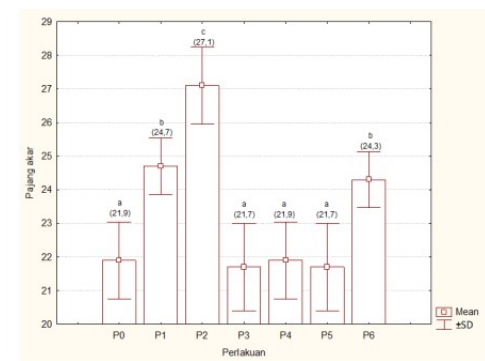

Gambar 7 Rata-rata panjang akar

Gambar 7 menunjukkan bahwa nilai ratarata panjang akar pada tanaman kangkung darat (Ipomoea reptans Poir.) tertinggi adalah P2 $(27,1 \mathrm{~cm})$ kemudian disusul oleh P1 $(24,70 \mathrm{~cm})$, P6 $(24,30 \mathrm{~cm})$, P0 $(21,90 \mathrm{~cm})$, P4 $(21,90 \mathrm{~cm})$ dan yang terendah adalah P3 $(21,70 \mathrm{~cm})$ dan P5 $(21,70 \mathrm{~cm})$.

Hasil penelitian menunjukkan bahwa pemberian pupuk organik cair berpengaruh nyata terhadap panjang akar. Nilai rata-rata tertinggi yaitu $P 2$, dan ISSN-P : 1978-6417; ISSN-E : 2580-5991 terendah yaitu P3 dan P5. Hal ini dikarenakan akar banyak menyerap air dan unsur hara dapat menopang berdirinya tanaman di tanah. Akar juga menghasilkan substansi pertumbuhan (zat pengatur tumbuh) yang diperlukan bagi tumbuhnya tanaman secara normal, dan perakaran tanaman sayur ini mempunyai peran yang sangat penting dalam pertumbuhan dan perkembangan tanaman sayur (Salamah \& Utami, 2009).

\section{SIMPULAN}

Sistem Penanaman melalui penerapan pupuk organik cair berpengaruh nyata terhadap pertumbuhan tanaman kangkung darat (Ipomoea reptans Poir.) Hasil Penelitian memperlihatkan pertumbuhan tertinggi pada tanaman kangkung darat yaitu P4 (27,34 cm), untuk jumlah daun P4 (14,90 helai), untuk berat segar tajuk P1 $(8,47 \mathrm{~g})$, untuk berat biomassa yaitu P1 (6,02 g), untuk berat tajuk segar P1 $(8,47$ g), untuk berat segar dan kering P1 (4,66 g), untuk kering daun P6 (2,07 g), nilai berat segar akar yaitu P1 (5,72 g), dan untuk kering akar P4 (1,61 g), dan untuk panjang akar yaitu P2 $(27,10 \mathrm{~cm})$.

\section{DAFTAR PUSTAKA}

Amalia, N. (2013). Identifikasi Jamur Aspergillus flavus pada Kacang Tanah (Arachis hypogaea L) yang Dijual di Pasar Kodim. Jurnal Analis Kesehatan Klinikal Sains, 1(1), 110.

Ariyono, R. Q., Djauhari, S., \& Sulistyowati, L. (2014). 
Keanekaragaman Jamur Endofit Akar Kangkung Darat ( Ipomoea reptans Poir.) Pada Lahan Pertanian Organik dan Konvesional. Keanekaragaman Jamur Endofit Daun Kangkung Darat (Ipomoea Poir). Pada Lahan Pertanian Organik Dan Konvensial., 2(1), 110.

Hardjo. S., (1989). Biokonversi Pemanfaatan Limbah Industri Pertanian. Bogor: Departemen Pendidikan dan Kebudayaan Direktorat Jenderal Pendidikan Tinggi Pusat antar Universitas Pangan dan Gizi, Institut Pertanian.

Hidayati, Y. A., Kurnani, T. B. A., \& Marlina, E. T. (2011). Kualitas Pupuk Cair Hasil Pengolahan Feses Sapi Potong Menggunakan Saccharomyces cereviceae ( Liquid Fertilizer Quality Produced by Beef Cattle Feces Fermentation Using Saccharomyces cereviceae ), 11(2), 104-107.

Iskandar, A. (2017). Optimalisasi Sekam Padi Bekas Ayam Petelur Terhadap Produktivitas Tanaman Kangkung Darat (Ipomoea reptans). Mimbar Agribisnis: Jurnal Pemikiran Masyarakat IImiah Berwawasan Agribisnis, $\quad 1(3), \quad 245$. https://doi.org/10.25157/ma.v1i3.44.

Jawetz E, Melnick dan Adelberg. (1996). Mikrobiologi Kedokteran. Jakarta: EGC.

Karimah., Purwanti, S., \& Rogomulyo, S. (2013). Kajian perendaman rimpang temulawak (Curcuma xanthorriza Roxb.) dalam unrin sapi dan air kelapa untuk mempercepat pertunasan. Vegetika, 2(2), 1-6.

Kaya, E. (2013). Pengaruh Kompos Jerami dan Pupuk NPK Terhadap $\mathrm{N}$-tersedia tanah, serapan-N, Pertumbuhan dan Hasil Padi Sawah (Oriza sativa L.) Agrologia 1(1),4350.

ISSN-P : 1978-6417; ISSN-E : 2580-5991
Lamusa, A. (2005). Faktor-faktor yang mempengaruhi produksi kangkung air di desa tulo kecamatan dolo kabupaten donggala propinsi sulawesi tengah. J. Agroland, 12(4), 512-517.

Manis, I., Supriadi, \& Said, I. (2017). Pendidikan Kimia/FKIP Universitas Tadulako, Palu Indonesia 94118, 6(November), 219-226.

Pancapalaga, W. (2011). Pengaruh Rasio Penggunaan Limbah Ternak dan Hijauan Tehadap Kualitas Pupuk Cair. Jurnal Gamma, 7(September), 61-68.

Rachmayanti, W. P. (2015). Info Artikel, 4(2252), 3-7.

Rahayu, S., \& Martono, D. S. (2015). “Uji Perkembang Biakan Miselia Bibit Jamur Tiram Putih ( Pleorutus ostreatus ) Dengan Substrat Campuran Air Kelapa dan Air Leri “. Agritek, 16(2), 47-60.

Rahmah, A., Izzati, M., \& Parman, S. (2014). Pengaruh Pupuk Organik Cair Berbahan Dasar Limbah Sawi ( Brassica chinensis L .) Terhadap Pertumbuhan Tanaman Jagung Manis (Zea mays L. var. Saccharata). Buletin Anatomi Dan Fisiologi, 22(1), 65-71. https://doi.org/10.1021/ol061681r

Ramadhani, G., \& Moesriati, A. (2013). Pemanfaatan Biji Asam Jawa ( Tamarindusindica ) Sebagai Koagulan Alternatif dalam Proses Menurunkan Kadar COD dan BOD dengan Studi Kasus pada Limbah Cair Industri Tempe. Jurnal Teknik Pomits, 2(1), 1-5.

Rizqiani, N. F., Ambarwati, E., \& Yuwono, N. W. (2007). The Effect of Dosage and Frequence of Liquid Organic Fertilizer on Growth and Yield of Lowland Beans (Phaseolus Vulgaris L.). Jurnal IImu Tanah Dan Lingkungan, 7(1), 43-53. Retrieved 
from

http://blog.ub.ac.id/puspitt/files/2012

/12/pupuk-cair.pdf

Salamah, Z., \& Utami, L. B. (2009).

Pemanfaatan Limbah Cair Industri
Tempe Untuk Meningkatkan Pertumbuhan Tanaman Kangkung Darat ( Ipomoea reptans , Poir ). Zuchros S, Suci $T W$, Listiatie $B$ U/P, 280-286. 